\title{
DO FEWER GUNS LEAD TO LESS CRIME? EVIDENCE FROM AUSTRALIA
}

\author{
Benjamin Taylor* \\ Harvard Law School
}

\author{
Jing $\mathrm{Li}^{\dagger}$ \\ Miami University
}

\begin{abstract}
The 1996 National Firearms Agreement (NFA) in Australia introduced strict gun control laws and facilitated the buyback of over 650,000 firearms. While several studies have investigated the effect of the NFA on firearm deaths, none has looked at its impact on crimes. In this paper we adopt the Difference-in-Difference identification approach to examine the impacts of the NFA on crimes. We find that one and two years after the NFA was enacted, there were significant decreases in armed robbery and attempted murder relative to sexual assault, with weaker evidence in relation to unarmed robbery.
\end{abstract}

Keywords: Gun Control Law; Difference-in-Difference; Crimes; Australia

JEL Classification: K29, C32

\footnotetext{
*Harvard Law School, 1563 Massachusetts Avenue, Cambridge, MA 02138. Phone: 617-496-8210. Email: btaylor@jd17.law.harvard.edu.

${ }^{\dagger}$ Corresponding Author. Department of Economics, 800 E. High Street, Miami University, Oxford, OH 45056. Phone: 513-529-4393. Fax: 513-529-6992. Email: lij14@miamioh.edu. We wish to thank William Even and Charles Moul for comments. All errors are ours.
} 
On April 28, 1996, Martin Bryant, a middle-aged psychologically disturbed man, killed 35 people in Port Arthur, Tasmania using a semiautomatic Armalite rifle and an SKS assault rifle. In an immediate response to the tragedy, the Australian Parliament enacted the National Firearms Agreement (NFA) and urged the eight Australian states-New South Wales, Victoria, Queensland, South Australia, West Australia, Tasmania, Northern Territory, and Australian Capital Territory to further tighten gun restrictions ${ }^{1}$. Between 1996 and 1997 the states heeded this plea from Parliament and enacted uniform gun control laws that prohibited the ownership, possession, and sale of automatic and semiautomatic weapons, limited handguns to target shooters with at least six months of target shooting experience, and strengthened requirements for licensing, registration, and safe storage of firearms.

Through the NFA, the Australian national government implemented a federally financed gun buyback and imposed a ban on the importation of semi-automatic firearms. By late 1997 over 650,000 guns were bought back and destroyed; this decrease, accompanied by the states' bans on firearms, reduced the number of guns in private hands by $20 \%$, and gun owning households by nearly $50 \% .^{2}$

\section{Empirical Literature}

Since Australia uniformly restricted gun ownership, and experienced no radical changes outside of its regulatory environment of guns, it has become the perfect case study to observe the effects of gun restrictions on criminal acts. In the literature there appears to be a consensus that the legislation decreased suicide rates significantly, yet there is debate concerning its

\footnotetext{
${ }^{1}$ Explanation of abbreviations and variables are given in Table 1.

${ }^{2} \mathrm{~A}$ more detailed description of the Port Arthur massacre and the NFA can be found in other sources such as Buchanan (2013).
} 
effect on homicide. ${ }^{3}$ Chapman et al. (2006) find that the NFA led to an accelerated decline in annual total gun deaths, but Baker and McPhedran (2006) discover that the effect of the NFA on gun related deaths was negligible. Later Leigh and Neil (2010) utilize panel data and show the NFA had an effect on firearm homicides, without affecting non-firearm death rates.

Note that previous studies have focused on the impact that the legislation had on deaths, with relatively little effort going to examine the effect on crime. As a result, these studies provide an incomplete evaluation of the NFA. This research attempts to make a contribution to the literature by filling that gap. In particular, we try to find the empirical evidence for the effect of the NFA on four crimes-armed robbery, attempted murder, sexual assault, and unarmed robbery. But first, it is instructive to compare two conflicting views about the effectiveness or ineffectiveness of the NFA.

\section{Two Views about Gun Restrictions}

In general, opponents of strict gun laws argue that said laws will be ineffective because unlawful citizens will still be able to obtain firearms via a black market. If true, then gun restrictions will only take guns out of the hands of law abiding citizens, ultimately making potential victims become less risky targets. For example, Lott and Mustard (1997) predict when criminals contemplate robbery or assault, they consider the probability that victims will protect themselves using their own guns. By banning guns, the risk of lethal retaliation is minimized, so the potential cost of performing a criminal act is decreased, especially when the aggressor has a gun, but the victim does not. This, in a sense, establishes that allowing certain people to own guns legally creates a positive externality by making it harder for criminals to know if the victim is armed before they strike, increasing the criminal's expected costs for committing crimes.

\footnotetext{
${ }^{3}$ For instance Leigh and Neil (2010) estimates that the NFA decreased suicide rates by $74 \%$.
} 
Proponents of strict gun laws think differently. While a black market may still exist, the ready availability of high-powered weapons is effectively altered. This alteration is a powerful tool in that it makes guns harder to obtain, which may dissuade petty criminals from using a weapon in their criminal act, or deter them from committing a criminal act in general. Marvell (2001) adds further support for this argument that gun bans decrease criminal gun ownership, by showing that they increase the expected cost of possessing a weapon: potential confiscation of the weapon, possible sanctions applied by juvenile officers, and the chance of being convicted and sentenced in a court of law make gun ownership relatively more expensive. As gun legislation becomes stricter, the cost of gun-possession will only increase due to the increased likelihood of sanctions or being sentenced in a court of law. Assuming that the probability that one will possess a gun is directly related to the cost of owning a gun, the increase in gun bans should greatly decrease gun ownership. If the decision to commit a crime is partially determined by the probability that the crime will be successful, and the probability of success is a function of weapon choice-guns pose a more severe threat to the victim, so the success of a crime is more likely-the reduction in gun ownership by criminals could make various crimes occur less frequently.

Our empirical findings will provide statistical evidences, and therefore shed more light on this debate.

\section{Data}

The data used in this paper come from annual state yearbooks and recorded crime reports of the Australian Bureau of Statistics. The recorded crime reports, which span from 1993 to 2010, comprise the number of sexual assault, attempted murder, armed robbery, and unarmed robbery incidents reported to the police in each calendar year. The definitions of these crimes, according to the Australian Standard Offence Classification (ASOC), are as 
follows: a sexual assault is a physical contact of a nature directed toward another person where that person does not give consent, gives consent as a result of intimidation or fraud, or consent is proscribed; an attempted murder is an attempted unlawful killing of another person where there is either the intent to kill, or the intent to cause grievous bodily harm with the knowledge that it was probable that death or grievous bodily harm would occur but where death did not actually occur; and an (un)armed robbery is an unlawful taking of property with the intent to permanently deprive the owner of the property, from the immediate possession, control, custody or care of a person, accompanied by the use, and/or threatened use of immediate force or violence.

Even though victimization data before 1993 are available, we do not use them in this paper due to the inconsistency of the data. The pre-1993 data were collected via an annual household survey that asked citizens if they had ever been victimized. Considering that these data came from a household survey, rather than police reports, and the survey did not specify the year in which the crimes occurred, they are not as informative as, and are inconsistent with, the recorded crime report.

The dependent variables are the crime rates, expressed as the number of crimes per 10,000 people. Following the literature (see Marvell (2001) and Raphael and Winter-Ebmer (2001) for instance) the confounding factors we have controlled for include (1) the annual unemployment rate in each state, which serves as the proxy for economy; (2) the number of sworn police officers at the end of each calendar year divided by the state population, which measures the size of law enforcement; (3) the number of prisoners divided by the state population; and (4) the percentage of youth population with ages 15-24. Table 1 provides detailed explanation of each variable.

Figure 1 plots the time series of standardized crime rates of armed robbery (denoted by triangle) and sexual assault (denoted by circle) in each state and the whole country, with a vertical line representing the year 1997. There is no strong indication that the two crime 
rates diverged in the years prior to 1997. However, after 1997 we see noticeable divergence in most states. For instance, in the populous New South Wales, there seems to be an upward trend in the sexual assault, whereas the trend for the armed robbery was inverted after 1997.

Figure 1 also indicates that the NFA may have lagged effect. In most states the turning point in the armed robbery trend did not occur until one or two years after 1997. In light of this, Table 2 compares average crime rates in the whole sample, and before and after 1999 . For the armed robbery the average rate is 2.988 before 1999 and 3.069 after 1999, and the difference is statistically insignificant (standard error $=0.280$ is in parentheses). By contrast, there is a significant and positive difference before and after 1999 for the sexual assault, indicating that the upward trend for the sexual assault had not been stopped.

Overall, Figure 1 and Table 2 motivate the Difference-in-Difference identification strategy.

\section{Fixed Effects Estimates and Difference-in-Difference Estiamtes}

We adopt the Difference-in-Difference (DID) identification strategy, with two critical assumptions: (1) the sexual assault and unarmed robbery ought not be affected by the gun-control law, therefore these two crimes can serve as placebos or control groups; (2) in the absence of the gun-control law, the state would have experienced changes in the armed robbery and attempted murder rates, which are the treatment groups, similar to the sexual assault and unarmed robbery. In other words, we assume the general crime trend can be approximated by sexual assault and unarmed robbery rates.

In reality sexual assaults may involve guns, but the actual percentage of the sexual assaults that involve guns is largely unobserved. Our view is that, as long as the majority of the sexual assaults are free of guns, our identification assumption still holds.

Notice that using the unarmed robbery as the control group may yield different results 
from the sexual assault, for several reasons. There may be substitution between the armed robbery and unarmed robbery after the NFA was enacted; police or prosecutors might be more likely to label unarmed robberies as thefts or assaults; robbers who previously committed both types of robberies may quit all together; or the pre-trend in the unarmed robbery may not like up with other crimes as well as the sexual assault does in Figure 1.

First, in order to show the effect of the NFA on each crime, Table 3 reports the fixed effects (FE) estimates. For the $m$-th crime $(m=$ armed robbery, attempted murder, sexual assault, and unarmed robbery), the model with unobserved heterogeneity is

$$
y_{i t}=\beta_{1} D_{98}+\beta_{2} D_{99}+\beta_{3} x_{i t}+c_{i}+\epsilon_{i t}
$$

where $y_{i t}$ is the crime rate, $i$ is the state index, $t$ is the time index, and $\epsilon_{i t}$ is the idiosyncratic error term. The dummy variables $D_{98}$ and $D_{99}$ are equal to ones after 1998 and 1999, respectively. Those two dummy variables can capture the lagged effects of the NFA on the crimes. The time-varying regressors $x_{i t}$ include unemployment rate, policing rate, young population rate and incarceration rate. We also include the state-specific linear time trends to account for the heterogeneity in the crime trend in each state. The trend variable can serve as proxy for time-varying unobserved effects. Finally, the state fixed effect $c_{i}$ can represent time-invariant unobserved factors. We do not include the year fixed effects because they would be collinear with $D_{98}, D_{99}$, and the state-specific trends.

Table 3 reports the FE estimation results, in which the $p$-values are in parentheses and are associated with the robust standard errors that are clustered at the state level. To interpret the results, note that $\beta_{1}$ and $\beta_{2}$ in (1) are constants. That means the fixed effects regression assumes, for a given crime, the effect of the law is state-invariant. As a result, those two coefficients measure the "average" or nationwide effects of the law across the states, one year and two years after the law was enacted. 
The estimation results are generally in consistent with Figure 1 and Table 2. For instance, Table 3 shows that the NFA on average has a negative effect on the armed robbery two years after the law was enacted (the p-values for $D_{99}$ are 0.062 and 0.119 without and with statespecific trends). Notice that for the sexual assault all the p-values of $D_{99}$ and $D_{98}$ are greater than 0.1, supporting the assumption that the sexual assault is unaffected by the NFA (so can be used as control). Nevertheless, for the unarmed robbery we see big p-values only for $D_{99}$. Thus using the unarmed robbery as the control is less convincing than the sexual assault.

The fixed effect regression (1) is limited in the sense that it fails to compare the trends across crimes. In particular, Table 3 may imply that the NFA has no effect on the attempted murder because all the p-values are greater than 0.1 . That implication would be wrong if the attempted murder had an altered trend that looks like Greek letter $\Lambda$. In that case, the mean for the upward trend before the turning point (the left leg of $\Lambda$ ) is likely to be insignificantly different from the downward trend after the turning point (the right leg of $\Lambda$ ). However, the NFA has significant effect because of the turning point.

The DID method can resolve this issue. More explicitly, we group the crimes as four treatment-control pairs: armed robbery vs sexual assault, armed robbery vs unarmed robbery, attempted murder vs sexual assault, and attempted murder vs unarmed robbery. For each pair we run the following two regressions

$$
\begin{aligned}
& y_{\text {mit }}=\alpha_{10}+\alpha_{11} D_{98}+\alpha_{12} D_{\text {treatment }}+\alpha_{13}\left(D_{98} \times D_{\text {treatment }}\right)+\alpha_{14} x_{i t}+c_{i}+\epsilon 1_{\text {mit }} \\
& y_{\text {mit }}=\alpha_{20}+\alpha_{21} D_{99}+\alpha_{22} D_{\text {treatment }}+\alpha_{23}\left(D_{99} \times D_{\text {treatment }}\right)+\alpha_{24} x_{i t}+c_{i}+\epsilon 2_{\text {mit }}
\end{aligned}
$$

where $m$ is the crime index, and the treatment dummy variable $D_{\text {treatment }}=1$ if the crime is the armed robbery or attempted murder. Note that both (2) and (3) are in the standard DID regression form with a time dummy, a treatment dummy and an interaction term of 
the two dummies. Model (2) uses $D_{98}$ as the time dummy, while (3) uses $D_{99}$.

The DID estimators are $\alpha_{13}$ and $\alpha_{23}$, which compare the before-and-after change in the treatment group to the control group. We expect negative DID estimates given that the before-and-after change is negative or close to zero for the treatment group, but positive or close to zero for the control group (see Table 2).

Our conjecture turns out to be true, according to Table 4, which reports the estimation results of (2) along with two p-values for the DID estimates. The conventional p-value is in parentheses, and is based on the cluster-robust standard error. The p-value from the permutation test of Fisher (1935) is in brackets ${ }^{4}$, and is obtained using the method 4 of Kennedy (1995). More explicitly, we regress $y_{m i t}$, the time dummy and the interaction term onto other regressors, and save the residuals. Then we regress the shuffled residualized $y_{m i t}$ on the residualized time dummy and the interaction term, and we run this shuffled regression 1000 times. The permutation-test p-value is the proportion that the t statistics of the shuffled DID estimates are greater (in absolute value) than the original t statistic.

Take armed robbery vs sexual assault. The DID estimates are -1.053 without statespecific trends, and -1.024 with state-specific trends. Without the trends, the conventional $\mathrm{p}$ value of the DID estimate is 0.049 , and the permutation-test $\mathrm{p}$-value is 0.055 . Those $\mathrm{p}$ values remain less than 0.1 with the trends. So the DID estimates indicate that the NFA had significantly reduced the armed robbery relative to the sexual assault. To evaluate the economic significance, we can divide the DID estimate by the sample mean of the crime rate. In this case, the NFA had cut the armed robbery about $30 \%$ relative to the sexual assault.

The deduction in the attempted murder is even more pronounced when comparing to the sexual assault. The NFA is shown to decrease the attempted murder by more than $70 \%$ relative to the sexual assault. However, such big differences across crimes vanish if the

\footnotetext{
${ }^{4}$ We are grateful to an anonymous referee for suggesting this alternative way of conducting hypothesis testing.
} 
unarmed robbery is used as the control group. This finding is actually expected since the unarmed robbery is less suitable for being used as the control group than the sexual assault.

There is no qualitative difference between Table 4 and Table 5, which reports the results of (3). There is some evidence that the effect of NFA two years after 1997 may be stronger than one year after 1997. Now the DID estimate is -1.507 for the pair of armed robbery vs sexual assault, greater (in absolute value) than -1.053 in Table 4.

\section{Robustness Checks}

We provide three robustness checks. First we re-run regression (3) using the standardized crime rate as the dependent variable. For the $m$-th crime, the standardized crime rate is computed as

$$
\tilde{y}_{m i t}=\frac{y_{m i t}-\bar{y}_{m}}{\text { standard deviation }}
$$

where $\bar{y}_{m}$ is the average $m$-th crime rate. The point of standardizing is to make the crime rate comparable to each other. Table 6 reports the result. The statistical significance of the DID estimate is qualitatively unchanged compared to Table 5. But now the DID estimate tells us how much deviation of the crime rate is changed after the NFA was enacted.

Second, to show the results are robust to the specification of the trend, we estimate the following regression that includes a national trend instead of state-specific trends:

$$
\begin{aligned}
y_{\text {mit }}=\theta_{j 0}+\theta_{j 1}\left(D_{j} \times t\right)+\theta_{j 2}\left(D_{\text {treatment }} \times t\right)+\theta_{j 3}\left(D_{j} \times D_{\text {treatment }} \times t\right) & \\
& +\theta_{j 4} x_{i t}+\theta_{j 5} t+c_{i}+\epsilon_{\text {mit }}, \quad(j=98,99) .
\end{aligned}
$$

Basically we multiply the dummy variables and interaction terms in (2) and (3) by the national trend $t$, and (5) uses the products as the regressors. The new regression can estimate the "average" or nationwide effect of the NFA on the trend of the crime (rather than the 
mean value of the crime). The coefficient of primary interest is $\theta_{j 3}$, the DID estimate in this setting, since it measures the difference in the before-and-after change of the trend slope across crimes. We exclude the state-specific trends since they are jointly collinear with the national trend.

Table 7 reports the results of (5) where the normalized year $($ nyear $=$ year $/ 1000)$ is used as the national trend $t$. This normalization is to avoid excessive number of zeros in the results. In general, the finding in Table 6 is consistent with Tables 4 and 5 . We see the trend slope is reduced significantly for the armed robbery and attempted murder relative to the sexual assault. On the other hand, there is no significant difference in the slope change if the unarmed robbery is the control.

Finally, another way to account for trending behavior is taking first difference. The point is, the standard regression theory is more reliable if we use the differenced data, which is stationary even though the original crime rate can be nonstationary. For the $m$-th crime in the $i$-th state, the differenced crime rate is

$$
\Delta y_{m i, t}=y_{m i, t}-y_{m i, t-1}
$$

Table 8 reports the results of estimating (3) using $\Delta y_{m i, t}$ as the dependent variable. Once again, the statistical significance of the DID estimate remains qualitatively unchanged compared to Table 5 .

\section{Conclusion and Discussion}

This paper takes an in depth look at the effects of the NFA on crimes rates. By using the Difference-in-Difference technique, we find evidence that the gun-control law had substantially reduced the rates of the armed robbery and attempted murder relative to the sexual assault. This finding is robust to the specification of the trend variables, the specification of 
the dependent variables, and the way that the $\mathrm{p}$ value is computed.

One limitation of this research is the lack of sufficiently long sample of reported crimes before 1997, which could be used to evaluate the common trends of various crimes before the gun-control law became effective. Another way to improve this study is to look at a country (if there is any) where its states or provinces implemented the gun-control law at different stages. Then we could treat the states that had not yet adopted the law as control groups, and use the varying time of law enactment to identify the effect of the gun-control law.

Cook and Ludwig (2000) documented that restricting access to firearms may lead to an increase in crimes that do not involve guns. At this point, the Australian data do not allow us to thoroughly check whether this type of substitution really occurred in that country. However, we want to remind the readers that, if the substitution is present, then our results only provide an upper bound of the true effect of the law.

When it comes to policy implications for the United States, some literature suggests the gun culture in US is too prevalent for a law like this to be effective. Opponents of strict gun legislation say that we have already tried gun buyback programs, and they have proven to be ineffective. While this is true, Levitt (2004) suggests that these buybacks failed for three reasons: (1) they were relatively small in scale, (2) guns surrendered voluntarily are not ones likely to be used for criminal activities, (3) replacement guns are easy to obtain. Unlike the United States, Australia is geographically isolated, making the illicit importation of weapons difficult. As a result, the emergence of a strong black market for weapons is less likely to occur in Australia than it would in a country with several bordering countries. This suggests that a future study may consider other island countries similar to Australia such as New Zealand and Ireland. 


\section{References}

Baker, J. and McPhedran, S. "Gun Laws and Sudden Death: Did the Australian Firearms Legislation of 1996 Make a Difference?" British Journal of Criminology, 47, (2006), 455-469.

Buchanan, K. Firearms-Control Legislation and Policy: Australia. Law Library of Congress, 2013.

Chapman, S., Alpers, P., Agho, K., and Jones, M. "Australia's 1996 Gun Law Reforms: Faster Fall in Firearm Deaths, Firearm Suicides and a Decade without Mass Shootings." Injury Prevention, 12, (2006), 365-372.

Cook, P. and Ludwig, J. Gun Violence, The Real Costs. Oxford University Press, 2000.

Fisher, R. A. The Design of Experiments. Edinburgh: Oliver and Boyd, 1935.

Kennedy, P. E. "Randomization Tests in Econometrics." Journal of Business 8 Economic Statistics, 13, (1995), 85-94.

Leigh, A. and Neil, C. "Do Gun Buybacks Save Lives? Evidence from Panel Data." American Law and Economics Review, 12, (2010), 462-508.

Levitt, S. "Understanding Why Crime Fell in the 1990s: Four Factors that Explain the Decline and Six that Do Not." Journal of Economic Perspectives, 18, (2004), 163-190.

Lott, J. and Mustard, D. "Crime, Deterrence, and Right-to-Carry Concealed Handguns." Journal of Legal Study, 26, (1997), 1-68.

Marvell, T. "The Impact of Banning Juvenile Gun Possession." Journal of Law and Economics, 44, (2001), 691-713. 
Raphael, S. and Winter-Ebmer, R. "Identifying the Effect of Unemployment on Crime." Journal of Law and Economics, 44, (2001), 259-284. 
Figure 1: Standardized Crime Rates Armed Robbery (triangle) and Sexual Assault (circle)
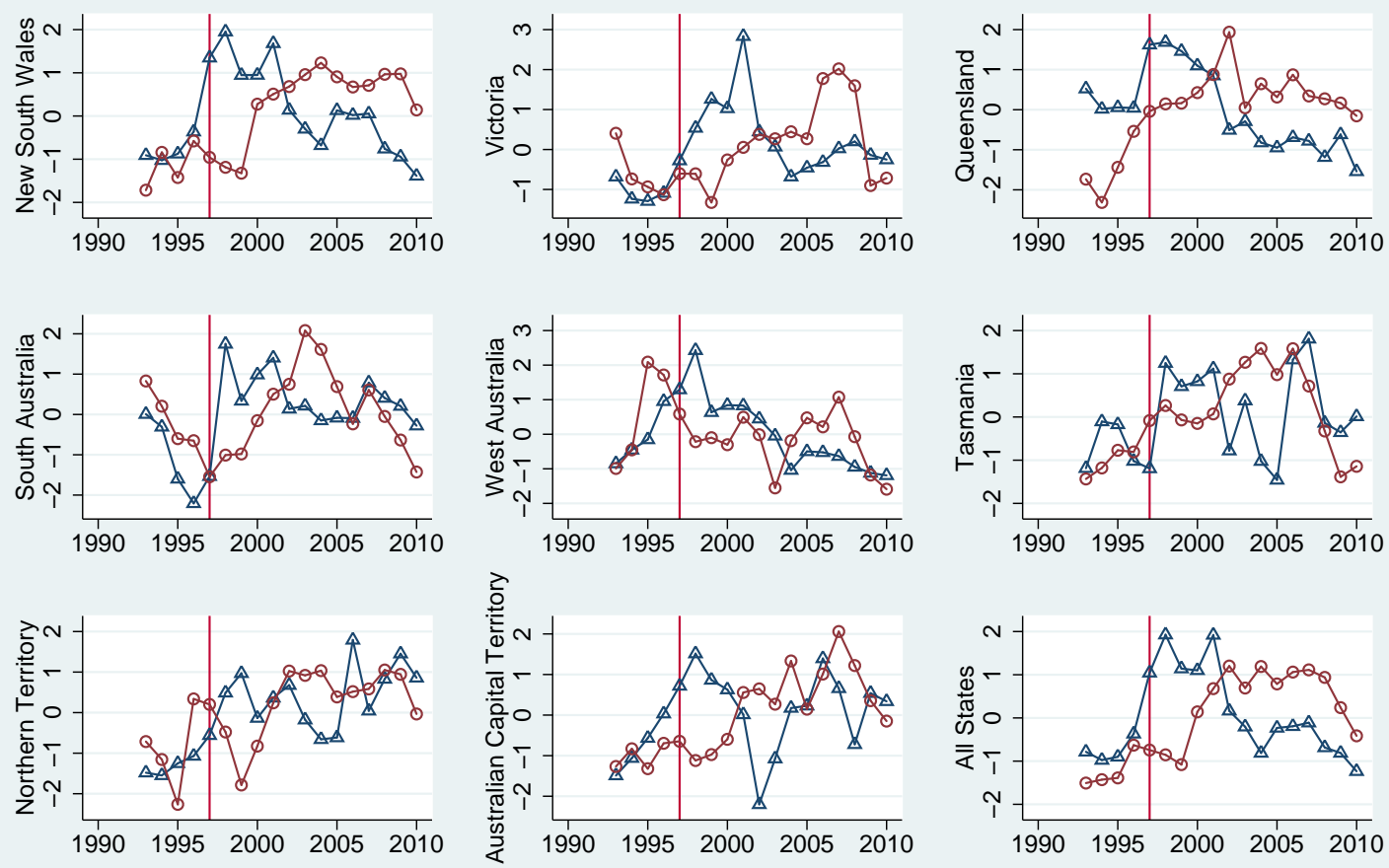
Variable

Time-Varying Controls

Population

Youth

Police

Prisoner

Unemployment

Treatment

Armed Robbery

Attempted Murder

Control

Sexual Assault

Unarmed Robbery

Independent Variables

$D_{98}$

$D_{98}$

Dtreatment
Explanation

State Population

(Population of Youth (15-24))/Population $\times 100$

(Number of Sworn Police Officers)/Population $\times 100$

(Number of Prisoners)/Population $\times 100$

Unemployment Rate (\%)

(Number of Armed Robberies)/Population $\times 10000$

(Number of Attempted Murders)/Population $\times 10000$

(Number of Sexual Assaults)/Population $\times 10000$

(Number of Unarmed Robberies)/Population $\times 10000$

$=0$ before 1998 and $=1$ after 1998

$=0$ before 1999 and =1 after 1999

$=0$ for Sexual Assault and Unarmed Robbery and =1 for Armed Robbery and Attempted Murder 
Table 2: Descriptive Statistics: Mean and Standard Deviation

\begin{tabular}{lllll}
\hline \hline & \multicolumn{5}{c}{ Crime Rates } \\
\cline { 2 - 5 } & Armed Robbery & Attempted Murder & Sexual Assault & Unarmed Robbery \\
Whole Sample & $3.042^{* * *}$ & $0.164^{* * *}$ & $8.276^{* * *}$ & $4.368^{* * *}$ \\
& $(0.131)$ & $(0.010)$ & $(0.271)$ & $(0.222)$ \\
Year $<1999$ (Before) & $2.988^{* * *}$ & $0.190^{* * *}$ & $7.279^{* * *}$ & $4.357^{* * *}$ \\
& $(0.264)$ & $(0.018)$ & $(0.435)$ & $(0.388)$ \\
Year $\geq 1999$ (After) & $3.069^{* * *}$ & $0.151^{* * *}$ & $8.775^{* * *}$ & $4.374^{* * *}$ \\
& $(0.147)$ & $(0.012)$ & $(0.333)$ & $(0.272)$ \\
After-Before & & & & \\
& 0.082 & $-0.038^{*}$ & $1.496^{* * *}$ & 0.016 \\
& $(0.280)$ & $(0.021)$ & $(0.563)$ & $(0.472)$ \\
\hline
\end{tabular}

Note:

The standard deviation or standard error is in parentheses. ${ }^{* * *},{ }^{* *}$, and ${ }^{*}$ denote significance at $1 \%, 5 \%$ and $10 \%$ levels, respectively. 
Table 3: Fixed Effects Estimation

\begin{tabular}{|c|c|c|c|c|c|c|c|c|}
\hline \multirow[b]{2}{*}{$D_{98}$} & \multicolumn{2}{|c|}{ Armed Robbery } & \multicolumn{2}{|c|}{ Attempted Murder } & \multicolumn{2}{|c|}{ Sexual Assault } & \multicolumn{2}{|c|}{ Unarmed Robbery } \\
\hline & $\begin{array}{l}1.718^{* * *} \\
(0.004)\end{array}$ & $\begin{array}{l}1.720^{* * *} \\
(0.005)\end{array}$ & $\begin{array}{l}-0.006 \\
(0.854)\end{array}$ & $\begin{array}{l}-0.009 \\
(0.811)\end{array}$ & $\begin{array}{l}-0.416 \\
(0.185)\end{array}$ & $\begin{array}{l}-0.311 \\
(0.455)\end{array}$ & $\begin{array}{l}0.890^{*} \\
(0.099)\end{array}$ & $\begin{array}{l}1.102^{* *} \\
(0.042)\end{array}$ \\
\hline$D_{99}$ & $\begin{array}{c}-1.024^{*} \\
(0.062)\end{array}$ & $\begin{array}{l}-0.637 \\
(0.119)\end{array}$ & $\begin{array}{l}-0.013 \\
(0.659)\end{array}$ & $\begin{array}{l}0.023 \\
(0.369)\end{array}$ & $\begin{array}{l}0.635 \\
(0.136)\end{array}$ & $\begin{array}{l}0.334 \\
(0.188)\end{array}$ & $\begin{array}{l}-0.616 \\
(0.130)\end{array}$ & $\begin{array}{l}0.251 \\
(0.444)\end{array}$ \\
\hline Time-Varying Controls & yes & yes & yes & yes & yes & yes & yes & yes \\
\hline State-Specific Trends & & yes & & yes & & yes & & yes \\
\hline
\end{tabular}

Note:

Each column represents a separate regression. The $p$-values are in parentheses and are based on the robust standard errors that are clustered at the state level. Time-Varying controls include unemployment rate, policing rate, young population rate and incarceration rate. ${ }^{* * *},{ }^{* *}$, and ${ }^{*}$ denote significance at $1 \%, 5 \%$ and $10 \%$ levels, respectively. 
Table 4: DID Estimates Using 1998 Dummy

\begin{tabular}{|c|c|c|c|c|c|c|c|c|}
\hline \multirow[b]{2}{*}{$D_{98}$} & \multicolumn{2}{|c|}{$\begin{array}{l}\text { Armed Robbery } \\
\text { vs Sexual Assault }\end{array}$} & \multicolumn{2}{|c|}{$\begin{array}{l}\text { Armed Robbery } \\
\text { vs Unarmed Robbery }\end{array}$} & \multicolumn{2}{|c|}{$\begin{array}{l}\text { Attempted Murder } \\
\text { vs Sexual Assault }\end{array}$} & \multicolumn{2}{|c|}{$\begin{array}{l}\text { Attempted Murder } \\
\text { vs Unarmed Robbery }\end{array}$} \\
\hline & $\begin{array}{l}1.080^{* * *} \\
(0.003)\end{array}$ & $\begin{array}{l}1.154^{* * *} \\
(0.001)\end{array}$ & $\begin{array}{l}0.593 \\
(0.347)\end{array}$ & $\begin{array}{l}1.077^{*} \\
(0.065)\end{array}$ & $\begin{array}{l}0.651^{*} \\
(0.097)\end{array}$ & $\begin{array}{l}0.593^{*} \\
(0.091)\end{array}$ & $\begin{array}{l}0.369 \\
(0.471)\end{array}$ & $\begin{array}{l}0.755^{*} \\
(0.098)\end{array}$ \\
\hline$D_{\text {treatment }}$ & $\begin{array}{l}-4.454^{* * *} \\
(0.005)\end{array}$ & $\begin{array}{l}-4.481^{* * *} \\
(0.005)\end{array}$ & $\begin{array}{l}-1.620^{*} \\
(0.058)\end{array}$ & $\begin{array}{l}-1.683^{*} \\
(0.057)\end{array}$ & $\begin{array}{l}-7.009 * * * \\
(0.000)\end{array}$ & $\begin{array}{l}-6.994^{* * *} \\
(0.000)\end{array}$ & $\begin{array}{l}-4.075^{* * *} \\
(0.003)\end{array}$ & $\begin{array}{l}-4.076^{* * *} \\
(0.004)\end{array}$ \\
\hline$D_{98} * D_{\text {treatment }}$ & $\begin{array}{l}-1.053^{* *} \\
(0.049) \\
{[0.055]}\end{array}$ & $\begin{array}{c}-1.024^{*} \\
(0.062) \\
{[0.077]}\end{array}$ & $\begin{array}{l}0.361 \\
(0.481) \\
{[0.279]}\end{array}$ & $\begin{array}{l}0.417 \\
(0.436) \\
{[0.542]}\end{array}$ & $\begin{array}{l}-1.511^{* *} \\
(0.010) \\
{[0.000]}\end{array}$ & $\begin{array}{l}-1.523^{* *} \\
(0.011) \\
{[0.000]}\end{array}$ & $\begin{array}{c}-0.219 \\
(0.612) \\
{[0.558]}\end{array}$ & $\begin{array}{c}-0.228 \\
(0.605) \\
{[0.401]}\end{array}$ \\
\hline Constant & $\begin{array}{l}14.556^{* * *} \\
(0.001)\end{array}$ & $\begin{array}{l}18.034^{* * *} \\
(0.005)\end{array}$ & $\begin{array}{l}10.429^{* *} \\
(0.023)\end{array}$ & $\begin{array}{l}18.192^{* *} \\
(0.030)\end{array}$ & $\begin{array}{l}12.077^{* * * *} \\
(0.001)\end{array}$ & $\begin{array}{l}13.457^{* * *} \\
(0.003)\end{array}$ & $\begin{array}{l}9.666^{* * *} \\
(0.007)\end{array}$ & $\begin{array}{l}14.969^{* *} \\
(0.015)\end{array}$ \\
\hline Time-Varying Controls & yes & yes & yes & yes & yes & yes & yes & yes \\
\hline State-Specific Trends & & yes & & yes & & yes & & yes \\
\hline
\end{tabular}

Note:

Each column represents a separate regression. The conventional $p$-values are in parentheses and are based on the robust standard errors that are clustered at the state level. The Fisher permutation-test $p$ value is in brackets. Time-Varying controls include unemployment rate, policing rate, young population rate and incarceration rate. ${ }^{* * *},{ }^{* *}$, and $*^{*}$ denote significance using conventional p-values at $1 \%, 5 \%$ and $10 \%$ levels, respectively. 
Table 5: DID Estimates Using 1999 Dummy

\begin{tabular}{|c|c|c|c|c|c|c|c|c|}
\hline \multirow[b]{2}{*}{$D_{99}$} & \multicolumn{2}{|c|}{$\begin{array}{l}\text { Armed Robbery } \\
\text { vs Sexual Assault }\end{array}$} & \multicolumn{2}{|c|}{$\begin{array}{l}\text { Armed Robbery } \\
\text { vs Unarmed Robbery }\end{array}$} & \multicolumn{2}{|c|}{$\begin{array}{l}\text { Attempted Murder } \\
\text { vs Sexual Assault }\end{array}$} & \multicolumn{2}{|c|}{$\begin{array}{l}\text { Attempted Murder } \\
\text { vs Unarmed Robbery }\end{array}$} \\
\hline & $\begin{array}{l}0.946^{* * *} \\
(0.008)\end{array}$ & $\begin{array}{l}1.032^{* * *} \\
(0.003)\end{array}$ & $\begin{array}{l}-0.183 \\
(0.679)\end{array}$ & $\begin{array}{l}0.384 \\
(0.205)\end{array}$ & $\begin{array}{l}0.855^{*} \\
(0.059)\end{array}$ & $\begin{array}{l}0.851^{* *} \\
(0.038)\end{array}$ & $\begin{array}{l}-0.075 \\
(0.840)\end{array}$ & $\begin{array}{l}0.381 \\
(0.222)\end{array}$ \\
\hline$D_{\text {treatment }}$ & $\begin{array}{l}-4.209^{* * *} \\
(0.008)\end{array}$ & $\begin{array}{l}-4.231^{* * *} \\
(0.008)\end{array}$ & $\begin{array}{l}-1.497^{*} \\
(0.059)\end{array}$ & $\begin{array}{l}-1.551^{*} \\
(0.058)\end{array}$ & $\begin{array}{l}-7.068^{* * *} \\
(0.000)\end{array}$ & $\begin{array}{l}-7.058^{* * *} \\
(0.000)\end{array}$ & $\begin{array}{l}-4.258^{* * *} \\
(0.003)\end{array}$ & $\begin{array}{l}-4.264^{* * *} \\
(0.003)\end{array}$ \\
\hline$D_{99} * D_{\text {treatment }}$ & $\begin{array}{l}-1.507^{* * * *} \\
(0.008) \\
{[0.002]}\end{array}$ & $\begin{array}{l}-1.484^{* *} \\
(0.011) \\
{[0.004]}\end{array}$ & $\begin{array}{l}0.199 \\
(0.681) \\
{[0.523]}\end{array}$ & $\begin{array}{l}0.248 \\
(0.616) \\
{[0.840]}\end{array}$ & $\begin{array}{l}-1.549 * * * \\
(0.008) \\
{[0.001]}\end{array}$ & $\begin{array}{l}-1.556^{* * *} \\
(0.009) \\
{[0.000]}\end{array}$ & $\begin{array}{l}0.035 \\
(0.925) \\
{[0.931]}\end{array}$ & $\begin{array}{l}0.032 \\
(0.931) \\
{[0.877]}\end{array}$ \\
\hline Constant & $\begin{array}{l}16.087^{* * * *} \\
(0.002)\end{array}$ & $\begin{array}{l}20.146^{* * *} \\
(0.008)\end{array}$ & $\begin{array}{l}14.318^{* *} \\
(0.020)\end{array}$ & $\begin{array}{l}23.095^{* *} \\
(0.029)\end{array}$ & $\begin{array}{l}11.333^{* * *} \\
(0.001)\end{array}$ & $\begin{array}{l}12.357^{* * *} \\
(0.006)\end{array}$ & $\begin{array}{l}11.172^{* * *} \\
(0.006)\end{array}$ & $\begin{array}{l}16.893^{* *} \\
(0.014)\end{array}$ \\
\hline Time-Varying Controls & yes & yes & yes & yes & yes & yes & yes & yes \\
\hline State-Specific Trends & & yes & & yes & & yes & & yes \\
\hline
\end{tabular}

Note:

Each column represents a separate regression. The conventional $p$-values are in parentheses and are based on the robust standard errors that are clustered at the state level. The Fisher permutation-test $p$ value is in brackets. Time-Varying controls include unemployment rate, policing rate, young population rate and incarceration rate. ${ }^{* * *},{ }^{* *}$, and $*^{*}$ denote significance using conventional p-values at $1 \%, 5 \%$ and $10 \%$ levels, respectively. 
Table 6: DID Estimates Using 1999 Dummy and Standardized Crime Rates

\begin{tabular}{|c|c|c|c|c|c|c|c|c|}
\hline \multirow[b]{2}{*}{$D_{99}$} & \multicolumn{2}{|c|}{$\begin{array}{l}\text { Armed Robbery } \\
\text { vs Sexual Assault }\end{array}$} & \multicolumn{2}{|c|}{$\begin{array}{l}\text { Armed Robbery } \\
\text { vs Unarmed Robbery }\end{array}$} & \multicolumn{2}{|c|}{$\begin{array}{l}\text { Attempted Murder } \\
\text { vs Sexual Assault }\end{array}$} & \multicolumn{2}{|c|}{$\begin{array}{l}\text { Attempted Murder } \\
\text { vs Unarmed Robbery }\end{array}$} \\
\hline & $\begin{array}{l}0.273^{* *} \\
(0.016)\end{array}$ & $\begin{array}{l}0.368^{* * *} \\
(0.002)\end{array}$ & $\begin{array}{l}-0.055 \\
(0.760)\end{array}$ & $\begin{array}{l}0.186 \\
(0.141)\end{array}$ & $\begin{array}{l}0.379^{*} \\
(0.088)\end{array}$ & $\begin{array}{l}0.532^{* *} \\
(0.018)\end{array}$ & $\begin{array}{l}0.083 \\
(0.716)\end{array}$ & $\begin{array}{l}0.385^{* *} \\
(0.041)\end{array}$ \\
\hline$D_{\text {treatment }}$ & $\begin{array}{l}0.274 \\
(0.591)\end{array}$ & $\begin{array}{l}0.275 \\
(0.591)\end{array}$ & $\begin{array}{l}-0.048 \\
(0.838)\end{array}$ & $\begin{array}{l}-0.074 \\
(0.755)\end{array}$ & $\begin{array}{l}0.500 \\
(0.163)\end{array}$ & $\begin{array}{l}0.496 \\
(0.170)\end{array}$ & $\begin{array}{l}0.157 \\
(0.759)\end{array}$ & $\begin{array}{l}0.128 \\
(0.800)\end{array}$ \\
\hline$D_{99} * D_{\text {treatment }}$ & $\begin{array}{l}-0.409^{* *} \\
(0.049)\end{array}$ & $\begin{array}{c}-0.415^{*} \\
(0.056)\end{array}$ & $\begin{array}{l}0.063 \\
(0.764)\end{array}$ & $\begin{array}{l}0.087 \\
(0.690)\end{array}$ & $\begin{array}{l}-0.761^{* * *} \\
(0.009)\end{array}$ & $\begin{array}{l}-0.763^{* *} \\
(0.010)\end{array}$ & $\begin{array}{l}-0.267 \\
(0.231)\end{array}$ & $\begin{array}{l}-0.238 \\
(0.285)\end{array}$ \\
\hline Constant & $\begin{array}{l}3.337^{*} \\
(0.088)\end{array}$ & $\begin{array}{l}5.586^{*} \\
(0.094)\end{array}$ & $\begin{array}{l}4.397 \\
(0.103)\end{array}$ & $\begin{array}{l}8.732^{*} \\
(0.071)\end{array}$ & $\begin{array}{l}-0.702 \\
(0.529)\end{array}$ & $\begin{array}{l}1.386 \\
(0.557)\end{array}$ & $\begin{array}{l}0.871 \\
(0.594)\end{array}$ & $\begin{array}{l}5.538^{*} \\
(0.096)\end{array}$ \\
\hline Time-Varying Controls & yes & yes & yes & yes & yes & yes & yes & yes \\
\hline State-Specific Trends & & yes & & yes & & yes & & yes \\
\hline
\end{tabular}

Note:

The dependent variable is the standardized crime rate. Each column represents a separate regression. The conventional $p$-values are in parentheses and are based on the robust standard errors that are clustered at the state level. Time-Varying controls include unemployment rate, policing rate, young population rate and incarceration rate. ${ }^{* * *},{ }^{* *}$, and ${ }^{*}$ denote significance using conventional p-values at $1 \%, 5 \%$ and $10 \%$ levels, respectively. 
Table 7: DID Estimates Using 1998 Dummy, 1999 Dummy and National Trends

\begin{tabular}{|c|c|c|c|c|c|c|c|c|}
\hline \multirow[b]{2}{*}{$D_{98} *$ nyear } & \multicolumn{2}{|c|}{$\begin{array}{l}\text { Armed Robbery } \\
\text { vs Sexual Assault }\end{array}$} & \multicolumn{2}{|c|}{$\begin{array}{l}\text { Armed Robbery } \\
\text { vs Unarmed Robbery }\end{array}$} & \multicolumn{2}{|c|}{$\begin{array}{l}\text { Attempted Murder } \\
\text { vs Sexual Assault }\end{array}$} & \multicolumn{2}{|c|}{$\begin{array}{l}\text { Attempted Murder } \\
\text { vs Unarmed Robbery }\end{array}$} \\
\hline & $\begin{array}{l}0.611^{* * *} \\
(0.002)\end{array}$ & & $\begin{array}{l}0.530^{*} \\
(0.077)\end{array}$ & & $\begin{array}{l}0.330^{*} \\
(0.055)\end{array}$ & & $\begin{array}{l}0.339 \\
(0.154)\end{array}$ & \\
\hline$D_{99} *$ nyear & & $\begin{array}{l}0.577^{* * *} \\
(0.001)\end{array}$ & & $\begin{array}{l}0.238 \\
(0.177)\end{array}$ & & $\begin{array}{l}0.452^{* *} \\
(0.020)\end{array}$ & & $\begin{array}{l}0.190 \\
(0.271)\end{array}$ \\
\hline$D_{98} * D_{\text {treatment }} *$ nyear & $\begin{array}{l}-0.511^{*} \\
(0.054)\end{array}$ & & $\begin{array}{l}0.195 \\
(0.446)\end{array}$ & & $\begin{array}{l}-0.738^{* *} \\
(0.011)\end{array}$ & & $\begin{array}{l}-0.101 \\
(0.639)\end{array}$ & \\
\hline$D_{99} * D_{\text {treatment }} *$ nyear & & $\begin{array}{l}-0.740^{* * *} \\
(0.009)\end{array}$ & & $\begin{array}{l}0.106 \\
(0.658)\end{array}$ & & $\begin{array}{l}-0.757^{* * *} \\
(0.009)\end{array}$ & & $\begin{array}{l}0.027 \\
(0.884)\end{array}$ \\
\hline nyear & $\begin{array}{l}-83.352 \\
(0.138)\end{array}$ & $\begin{array}{l}-80.607 \\
(0.110)\end{array}$ & $\begin{array}{l}-256.116^{* *} \\
(0.025)\end{array}$ & $\begin{array}{l}-243.897^{* *} \\
(0.027)\end{array}$ & $\begin{array}{l}-12.188 \\
(0.770)\end{array}$ & $\begin{array}{l}-22.258 \\
(0.583)\end{array}$ & $\begin{array}{l}-163.342^{* *} \\
(0.034)\end{array}$ & $\begin{array}{l}-165.138^{* *} \\
(0.040)\end{array}$ \\
\hline$D_{\text {treatment }} *$ nyear & $\begin{array}{l}-2.239 * * * \\
(0.005)\end{array}$ & $\begin{array}{l}-2.113^{* * *} \\
(0.008)\end{array}$ & $\begin{array}{l}-0.829^{*} \\
(0.054)\end{array}$ & $\begin{array}{c}-0.759^{*} \\
(0.057)\end{array}$ & $\begin{array}{l}-3.513^{* * *} \\
(0.000)\end{array}$ & $\begin{array}{l}-3.542^{* * *} \\
(0.000)\end{array}$ & $\begin{array}{l}-2.041^{* * *} \\
(0.003)\end{array}$ & $\begin{array}{l}-2.133^{* * *} \\
(0.003)\end{array}$ \\
\hline Constant & $\begin{array}{l}183.152 \\
(0.116)\end{array}$ & $\begin{array}{l}178.908^{*} \\
(0.090)\end{array}$ & $\begin{array}{l}528.486^{* *} \\
(0.024)\end{array}$ & $\begin{array}{l}506.968^{* *} \\
(0.026)\end{array}$ & $\begin{array}{l}36.765 \\
(0.668)\end{array}$ & $\begin{array}{l}56.311 \\
(0.500)\end{array}$ & $\begin{array}{l}339.946^{* *} \\
(0.032)\end{array}$ & $\begin{array}{l}344.631^{* *} \\
(0.038)\end{array}$ \\
\hline Time-Varying Controls & yes & yes & yes & yes & yes & yes & yes & yes \\
\hline
\end{tabular}

Note:

Each column represents a separate regression. The conventional $p$-values are in parentheses and are based on the robust standard errors that are clustered at the state level. Time-Varying controls include unemployment rate, policing rate, young population rate and incarceration rate. ${ }^{* * *},{ }^{* *}$, and ${ }^{*}$ denote significance using conventional p-values at $1 \%, 5 \%$ and $10 \%$ levels, respectively. 
Table 8: DID Estimates Using 1999 Dummy and Differenced Crime Rates

\begin{tabular}{|c|c|c|c|c|c|c|c|c|}
\hline \multirow[b]{2}{*}{$D_{99}$} & \multicolumn{2}{|c|}{$\begin{array}{l}\text { Armed Robbery } \\
\text { vs Sexual Assault }\end{array}$} & \multicolumn{2}{|c|}{$\begin{array}{l}\text { Armed Robbery } \\
\text { vs Unarmed Robbery }\end{array}$} & \multicolumn{2}{|c|}{$\begin{array}{l}\text { Attempted Murder } \\
\text { vs Sexual Assault }\end{array}$} & \multicolumn{2}{|c|}{$\begin{array}{l}\text { Attempted Murder } \\
\text { vs Unarmed Robbery }\end{array}$} \\
\hline & $\begin{array}{l}1.365^{* * *} \\
(0.005)\end{array}$ & $\begin{array}{l}1.533^{* * *} \\
(0.002)\end{array}$ & $\begin{array}{l}-0.132 \\
(0.794)\end{array}$ & $\begin{array}{l}0.348 \\
(0.287)\end{array}$ & $\begin{array}{l}1.314^{* *} \\
(0.011)\end{array}$ & $\begin{array}{l}1.363^{* *} \\
(0.011)\end{array}$ & $\begin{array}{l}-0.173 \\
(0.731)\end{array}$ & $\begin{array}{l}0.240 \\
(0.496)\end{array}$ \\
\hline$D_{\text {treatment }}$ & $\begin{array}{l}1.146^{* *} \\
(0.017)\end{array}$ & $\begin{array}{l}1.107^{* *} \\
(0.025)\end{array}$ & $\begin{array}{l}-0.197 \\
(0.621)\end{array}$ & $\begin{array}{l}-0.208 \\
(0.602)\end{array}$ & $\begin{array}{l}1.339 * * \\
(0.011)\end{array}$ & $\begin{array}{l}1.305^{* *} \\
(0.017)\end{array}$ & $\begin{array}{l}-0.041 \\
(0.882)\end{array}$ & $\begin{array}{l}-0.044 \\
(0.874)\end{array}$ \\
\hline$D_{99} * D_{\text {treatment }}$ & $\begin{array}{l}-1.693^{* *} \\
(0.023)\end{array}$ & $\begin{array}{l}-1.685^{* *} \\
(0.028)\end{array}$ & $\begin{array}{l}0.209 \\
(0.710)\end{array}$ & $\begin{array}{l}0.218 \\
(0.707)\end{array}$ & $\begin{array}{l}-1.955^{* *} \\
(0.017)\end{array}$ & $\begin{array}{l}-1.944^{* *} \\
(0.020)\end{array}$ & $\begin{array}{l}-0.013 \\
(0.976)\end{array}$ & $\begin{array}{l}-0.009 \\
(0.984)\end{array}$ \\
\hline Constant & $\begin{array}{l}6.144 \\
(0.278)\end{array}$ & $\begin{array}{l}7.039 \\
(0.391)\end{array}$ & $\begin{array}{l}9.477 \\
(0.123)\end{array}$ & $\begin{array}{l}22.572^{*} \\
(0.065)\end{array}$ & $\begin{array}{l}3.546 \\
(0.376)\end{array}$ & $\begin{array}{l}1.504 \\
(0.727)\end{array}$ & $\begin{array}{l}6.873 \\
(0.131)\end{array}$ & $\begin{array}{l}16.188^{* *} \\
(0.043)\end{array}$ \\
\hline Time-Varying Controls & yes & yes & yes & yes & yes & yes & yes & yes \\
\hline State-Specific Trends & & yes & & yes & & yes & & yes \\
\hline
\end{tabular}

Note:

The dependent variable is the differenced crime rate. Each column represents a separate regression. The conventional $p$-values are in parentheses and are based on the robust standard errors that are clustered at the state level. Time-Varying controls include unemployment rate, policing rate, young population rate and incarceration rate. ${ }^{* * *},{ }^{* *}$, and ${ }^{*}$ denote significance using conventional p-values at $1 \%, 5 \%$ and $10 \%$ levels, respectively. 